\title{
Changes in Endocrine Profiles and Spermiation Response in Carp after LHRH Analogue Injection
}

\author{
Somsri Ngamvongchon, ${ }^{* 1,2}$ Law Yean Kok, ${ }^{* 3}$ and Fumio Tahashima ${ }^{* 1,4}$ \\ (Accepted June 24, 1986)
}

\begin{abstract}
LHRH analogue [(D-Ala -desGly $\left._{10}\right)$ LHRH ethylamide] injection at a dose of $30 \mu \mathrm{g} / \mathrm{kg}$ body weight accelerated spermiation in carp. The amount of collectable milt increased rapidly at $12 \mathrm{~h}$ after injection and was maintained at high levels for $24 \mathrm{~h}$. The spermatocrit gradually increased throughout the experiment, and motility of the spermatozoa did not appear to be affected.

Plasma gonadotropin (GtH) level showed a significant rise at 5 min after the LHRH analogue injection. The level decreased at $40 \mathrm{~min}$ but increased again gradually and reached a peak at $24 \mathrm{~h}$. The control group had a lower plasma $\mathrm{GtH}$ level than the injected group throughout the experiment. Plasma testosterone increased significantly from $1 \mathrm{~h}$ and was maintained at a high level for $24 \mathrm{~h}$. Plasma 11-ketotestosterone also showed a similar pattern of changes. No significant changes were recognized for both androgens in the control fish.

From these results, it is possible to postulate that exogenous LHRH analogue stimulated an early and rapid discharge of gonadotropin from the pituitary gland, and that spermiation was enhanced by the action of the successive secretion of gonadotropin and androgens.
\end{abstract}

Many investigations carried out on mammals, birds and reptiles have shown that some of the synthetic LHRH and their analogues (LHRH-a) have the same biological properties as the natural hypothalamic releasing factors, as these substances will induce oocyte maturation and ovulation in female and spermiation in males. ${ }^{1-\eta)}$ Similar results have been obtained in female fish such as carp, ${ }^{8)}$ rainbow trout, ${ }^{, 2}$ Atlantic salmon, ${ }^{10)}$ goldfish, ${ }^{11-18)}$ medaka, ${ }^{14)}$ ayu, ${ }^{13)}$ plaice and goby, ${ }^{1{ }^{18}}$ Tinc $a{ }^{17}{ }^{17} \quad$ Hypothalmichtys, ${ }^{19)}$ and Chinese carp. ${ }^{18,20)}$ In these fishes, oocyte maturation and ovulation were accelerated after injection with LHRH or its analogue. Spermiation was also accelerated after administration of LHRH-a in pike, ${ }^{21)}$ carp $^{222}$ and Atlantic salmon ${ }^{23)}$ also stimulated spermiation. The results of a recent experiment by one of the authors (FT) indicated that LHRH-a effectively stimulated spermiation in carp. ${ }^{24)}$

The purpose of this study was to investigate the early responses of the endocrine system, especially the plasma GtH and androgen changes and the spermiation response, of carp within $24 \mathrm{~h}$ after treatment with LHRH-a. In addition, the histological changes of the gonadotrophs were also investigated by electron microscopy.

\section{Materials and Methods}

The experiments were carried out at the laboratory of Fish-Culture, Tokyo University of Fisheries, from March to April 1985. Threeyear-old male carp with an average weight of 1.2$2.0 \mathrm{~kg}$ were used. Before handling, the fish were anesthetized with $350 \mathrm{ppm}$ 2-phenoxyethanol. The males that gave a slight amount of milt after hand stripping were selected for this experiment.

Five to eight males were either injected intraperitoneally with $0.9 \% \mathrm{NaCl}$ as a control group or with LHRH analogue [(D-Ala ${ }_{8}$-desGly $\left._{10}\right)$ LHRH ethylamide] at a dose of $30 \mu \mathrm{g} / \mathrm{kg}$ body weight.

Milt was obtained by hand stripping just before injection and at 5 and $30 \mathrm{~min}$, and at $1,3,6,12$, 24 , and $48 \mathrm{~h}$ after injection. About $0.1 \mathrm{~m} l$ of blood was also obtained using heparinized syringes from the caudal vasculature at each

*1 Laboratory of Fish-Culture, Tokyo University of Fisheries, Konan 4-5-7, Minato, Tokyo 108, Japan (y ムスイ・ヌガヴォンチョ，隆島史夫：東京水産大学).

*2 Permanent address: National Inland Fisheries Institute, Bangkok, Thailand ( 1 国立内水面漁莱研究 所).

*8 Laboratory of Fish Physiology, the University of Tokyo, Bunkyo, Tokyo 113, Japan (ロー・エン・コ ク: 東京大学農学部).

*4 To whom correspondence should be addressed. 
sampling time. After centrifugation at $3600 \mathrm{rpm}$ the plasma was separated and stored at $-70^{\circ} \mathrm{C}$ until analysis. Spermatocrit was measured with a hemacytometer using microhematocrit tubes sealed at one end and centrifuged at $12,000 \mathrm{rpm}$ for $5 \mathrm{~min}$. Sperm motility was classified under the light microscope using $1 \mu l$ of stripped milt diluted with $100 \mu l$ of distilled water. The types of spermatozoa movement was recorded as following: forward movement $(t++)$, rotatory movement $(+t)$, vibration movement $(t)$, and no movement $(-)$. The duration of movement was determined from the time of activation by distilled water until the end of movement.

Plasma GtH was measured using a double antibody radio-immunoassay (RIA) with a purified preparation of silver carp gonadotropin described by Kobayashi et al. $^{28)}$

Plasma testosterone, 11-ketotestosterone and $17 \alpha, 20 \beta$ dihydroxyprogesterone were measured by RIA according to the method developed by Aida et $a l .{ }^{16)}$ and Kobayashi et al. ${ }^{26)}$ respectively.

During the experiment, fish were kept individually in $36 l$ tanks with dechlorinized slowrunning water, and the water temperature averaged $19^{\circ} \mathrm{C}$.

Duncan's multiple-range test was used to determine differences among experimental groups.

The pituitaries were removed from 2 or 3 fishes sacrificed before injection or $5 \mathrm{~min}$ and $24 \mathrm{~h}$ after injection with LHRH-a, and were fixed in glutaldehyde-osmium solution. Ultrathin sections were made after embedding in Quetol 812, and stained with Pb-nitrate.

\section{Results}

\section{Volume of Milt}

At 5 and $30 \mathrm{~min}$, and 1 and $3 \mathrm{~h}$ following LHRH-a injection, the amount of collectable milt per body weight was less than $0.02 \%$ and not significantly different from the control group. However, the milt volume rapidly increased $12 \mathrm{~h}$ after the injection and remained elevated for $24 \mathrm{~h}$; then, slightly decreased after $48 \mathrm{~h}$ (Fig. 1). The amount of milt from control fish was low at $6 \mathrm{~h}$ and slightly increased at $12 \mathrm{~h}$, after which time it decreased.

\section{Spermatocrit}

The spermatocrit value before injection was $16.3 \pm 10.69 \%$ and increased gradually from $18.3 \pm 10.14$ to $47.8 \pm 5.72 \%$ after injection. In the control group the spermatoclit was measured on the males which gave small amount of the milt at $24 \mathrm{~h}$ after $0.9 \% \mathrm{NaCl}$ injection.

\section{Sperm Motility}

It was found that the spermatozoa of carp were usually motionless in undiluted sperm, but became active after dilution with distilled water. In the control fish, which scarcely gave milt at $24 \mathrm{~h}$, the rate of spermatozoa movement began from forward movement $(+++)$ and stopped within about $1 \mathrm{~min}(45-67 \mathrm{sec})$. In the LHRH-a injected fish, energetic forward movement $(+++)$ of most spermatozoa in the milt obtained in each time began at the time of activation and then stopped within $1 \mathrm{~min}$.

\section{Plasma GtH}

Plasma GtH before injection was $8.8 \pm 0.38$ $\mathrm{ng} / \mathrm{ml}$. In the LHRH-a injected group, plasma GtH level increased at $5 \mathrm{~min}$ to $40.5 \pm 11.0 \mathrm{ng} / \mathrm{ml}$. The levels, however, decreased rapidly at $30 \mathrm{~min}$ reaching a level of $14.1 \mathrm{ng} / \mathrm{ml}$. This level was not statistically different from that of the control group $(9.0 \pm 0.20 \mathrm{ng} / \mathrm{ml})$. At $6 \mathrm{~h}$, plasma $\mathrm{GtH}$ gradually increased again reaching a peak at $24 \mathrm{~h}$ $(51.2 \pm 12.35 \mathrm{ng} / \mathrm{m} l)$. The control group had a plasma GtH range from $7.8 \pm 0.34 \mathrm{ng} / \mathrm{m} l$ to $9.2 \pm$ $0.5 \mathrm{ng} / \mathrm{m} l$ throughout the experiment (Fig. 1).

\section{Plasma Androgens}

Before LHRH-a injection, plasma testosterone and $11-\mathrm{ketotestosterone} \mathrm{were} 6.5 \pm 2.5 \mathrm{ng} / \mathrm{m} l$ and $3.4 \pm 1.0 \mathrm{ng} / \mathrm{m} l$, respectively. At $1 \mathrm{~h}$, plasma testosterone had increased significantly to $14.6 \pm$ $4.7 \mathrm{ng} / \mathrm{ml}$, and also at $3 \mathrm{~h}$ to a level of $22.6 \pm 3.0$ $\mathrm{ng} / \mathrm{m} /$ (Fig. 1). It was maintained at a high level for $12 \mathrm{~h}$ but it decreased after $24 \mathrm{~h}$.

Plasma 11-ketotestosterone increased significantly at $1 \mathrm{~h}$ to a level of $5.8 \pm 1.58 \mathrm{ng} / \mathrm{ml}$ and reached $13.6 \pm 7.98 \mathrm{ng} / \mathrm{ml}$ at $3 \mathrm{~h}$. The level was still high at $24 \mathrm{~h}$ with $25.9 \pm 10.0 \mathrm{ng} / \mathrm{ml}$.

In the control group, both testosterone and 11ketotestosterone showed a slight increase from $3 \mathrm{~h}$ to $12 \mathrm{~h}$, but this increase was not statistically significant. Plasma $17 \alpha, 20 \beta$-dihydroxyprogessterone levels were varied among individuals and showed no statistical significance between injected and control groups.

\section{Gonadotrophs}

The gonadotrophs of carp were thought to be the larger basophilic cells in the meso-adenohypophysis which possessed the granules of different size. Some of them contained large 


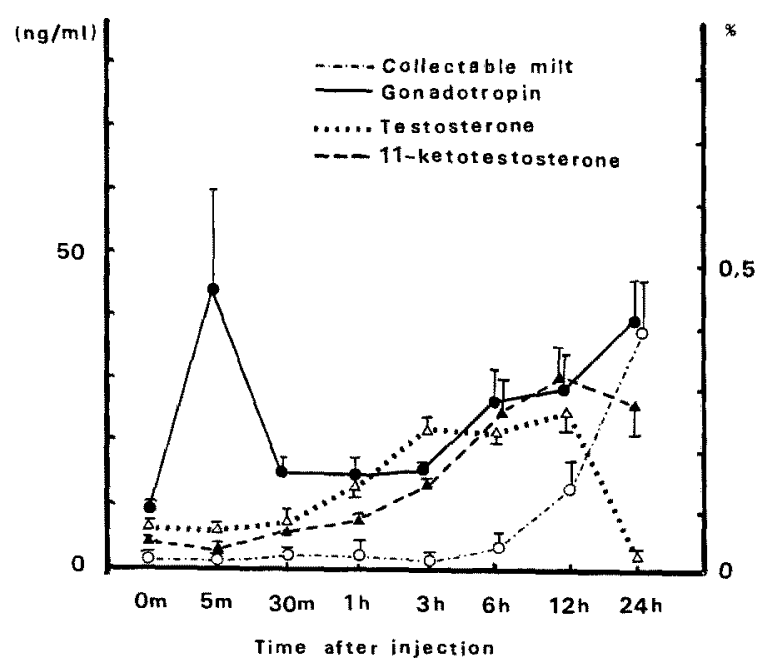

Fig. 1. Changes in the amount of collectable milt (expressed as percent to the body weight) and the levels of plasma gonadotropin $(\mathrm{GtH})$ as well as androgrens (testosterone and 11-ketotestosterone) in male carp after LHRH-analogue injection.

vacuoles within the cytoplasm (Fig. 2A). Larger granules were usually round in shape, while middle-sized and small granules were round or ellipsoidal.

Five min after LHRH-a injection, most of the gonadotrophs reduced in size and almost all large and middle-zized granules as well as the intracellular vacuoles had disappeared (Fig. 2B). Small and somewhat ellipsoidal granules were condensed in the periphery of cytoplasm. Most parts of intercellular spaces expanded and contained some materials probably discharged from the gonadotrophs.

The gonadotrophs at $24 \mathrm{~h}$ after injection contained both large and middle-sized granules. While the small granules were less in number. Plentiful intercellular spaces were also observed.

\section{Discussion}

The purpose of this study was to examine the changes in plasma $\mathrm{GtH}$ and androgen levels and the spermiation responses of carp after LHRH-a injection over a period of $24 \mathrm{~h}$. It was found that LHRH-a at a dose of $30 \mu \mathrm{g} / \mathrm{kg}$ body weight could cause an elevation in plasma $\mathrm{GtH}$ level and also accelerate spermiation. The amount of milt increased rapidly at $12 \mathrm{~h}$ after injection and was maintained high for $24 \mathrm{~h}$, after which time it decreased. Almost all the spermatozoa in the milt from LHRH-a injected animals showed immediate active forward movement. The duration of movement after activation was quite similar to that reported by Ginzburg, ${ }^{26)}$ and indicated that the spermatozoa possessed a good quality of motility.

The present results suggested that LHRH-a stimulated the secretion of $\mathrm{GtH}$ from the pituitary gland within a short time since plasma $\mathrm{GtH}$ was already elevated at $5 \mathrm{~min}$ after injection. Plasma $\mathrm{GtH}$, in turn, stimulated production of the androgens such as testosterone and 11-ketotestosterone, which may eventually control the spermiation process.

Several previous studies have tried to identify the trigger of spermiation. Takashima et al. ${ }^{24}$ found that the amount of milt and 11-ketotestosterone in serum were both increased following an elevation in plasma $\mathrm{GtH}$, artificially evoked with LHRH-a injection in carp. However, Yamazaki and Donaldson ${ }^{27)}$ suggested that the spermiation in goldfish was regulated by 17 methyltestosterone and dehydroepiandrosterone. In rainbow trout, it was found that the concentration of 11-ketotestosterone was high in spermiating male ${ }^{28)}$ but very low in females. ${ }^{29)}$ Fostier et al. ${ }^{30)}$ reported that the quantities of collectable milt in rainbow trout were positively correlated with 11 ketotestosterone levels, but not with GtH levels. Hunt et $a{ }^{31}{ }^{31}$ analysed serum testosterone and 11ketotestosterone in rainbow trout after $\mathrm{GtH}$ injection and observed early rise in the former 

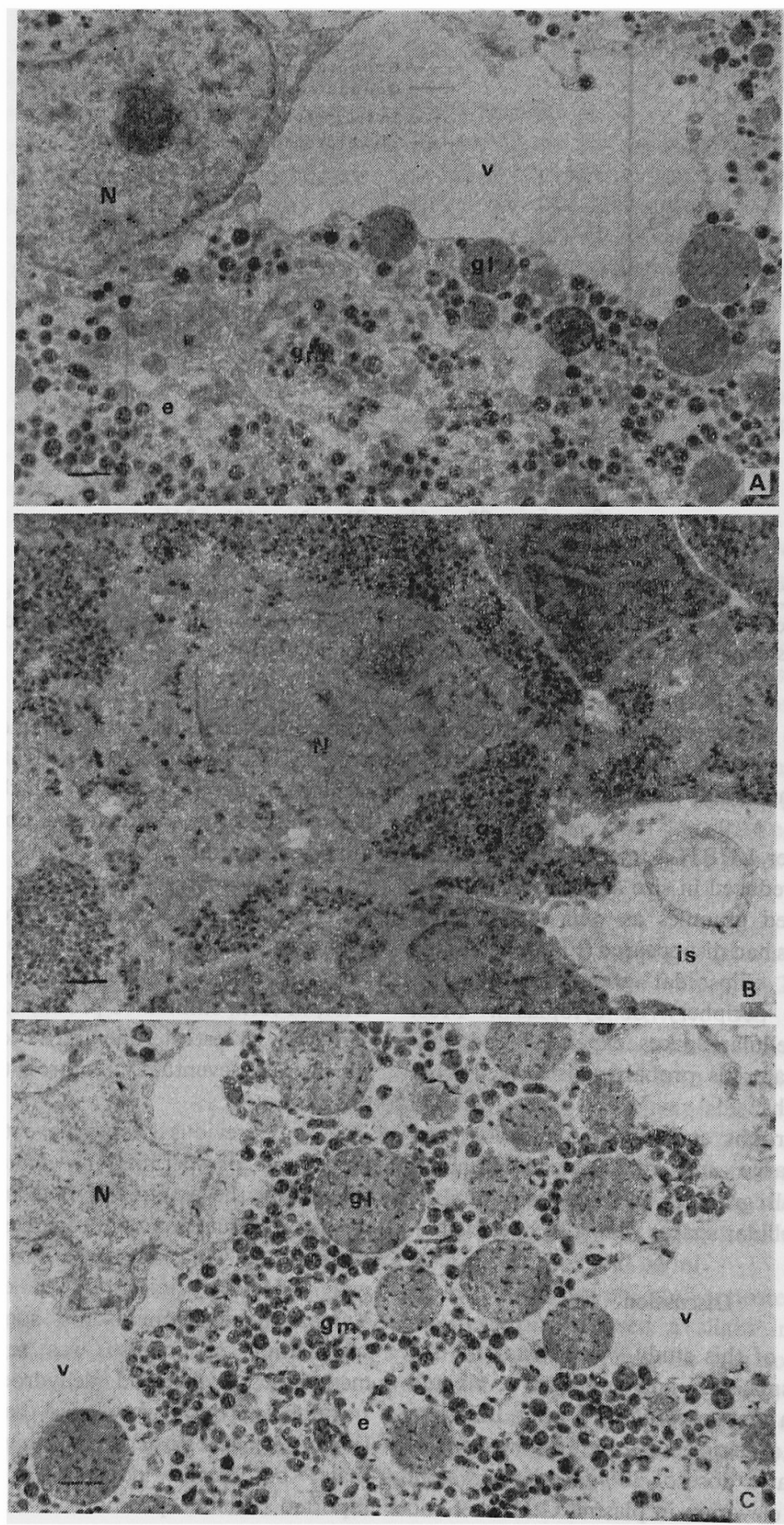

Fig. 2. Histological changes in the gonadotrophs of male carp after LHRH-analogue injection. A: Before injection, Large (gl) and middle-sized as well as small granules of various sizes (gm) are distributed in the cell, A part of endoplasmic reticuli (e) is dilated. $\mathrm{N}$; nucleus, Large vacuole (v) can be seen.

B: Five min after LHRH-analogue injection, Large and middle-sized granules 
followed by an increase in the later. These results taken together seem to indicate that the testosterone and 11-ketotestosterone play key roles in the process of spermiation.

On the other hand, Kobayashi et al. ${ }^{32)}$ reported the effectiveness of HCG on induction of collectable milt in goldfish, and postulated involving role of testosterone and 11-ketotestosterone in spermatogeneis and $17 \alpha, 20 \beta$-dihydroxyprogesterone in spermiation. Similar explanations for the action of testicular steroid were presented in salmonid fish. $^{33-35)}$

In the present study, plasma testosterone and 11-ketotestosterone were both increased at $1 \mathrm{~h}$ after LHRH-a injection. 11-ketotestosterone continued to increase for $6 \mathrm{~h}$, while testosterone reached maximum levels after $3 \mathrm{~h}$ and had decreased at $24 \mathrm{~h}$. The role of $17 \alpha, 20 \beta$-dihydroxyprogesterone was not clear in this study because of individual variations in plasma concentration. A possible explanation for these observations is that testosterone produced in the testis in response to GtH may be gradually transformed to 11ketotestosterone and accelerate the spermiation.

The depletion of secretory granules from the gonadotrophs and dilatation of intercellular spaces among the gonadotrophs at $5 \mathrm{~min}$ after LHRH-a injection indicate active discharge of the secretory substances. This phenomenon may be causally related to the rapid increase in plasma $\mathrm{GtH}$ in the males receiving LHRH-a. On the other hand, within the gonadotrophs of the male at $24 \mathrm{~h}$ after the injection, both large granules and vacuoles were observed. Thus, it is possible that the increase in plasma $\mathrm{GtH}$ observed after $6 \mathrm{~h}$ of injection may be the result of de novo synthesis and subsequent discharge of GtH. However, the mechanism for this bimodal discharge of $\mathrm{GtH}$ from the pituitary gland after LHRH-a injection is unclear because of insufficient informations concerning biological half-time of exogeneous LHRH or its analogues, we can not conclude that the exogeneous LHRH-a is enough to stimilate GtH secretion from the pituitary gland after several hours. The possibility that the concentration of LHRH-a injected is enough to stimulate GtH secretion from the pituitary gland after several hours should be checked experimentally.
The possibility of involvement of positive feedback system should be also examined.

In conclusion, the present results clearly showed that exogenous LHRH-a can stimulate rapid discharge of stored $\mathrm{GtH}$ from the pituitary gland, followed later by androgen production and ultimately, spermiation. From an aquacultural point of view, the technique used in this study seems appropriate to obtain milt from male carps during the spawning season.

\section{Acknowledgements}

We wish to express our sincere thanks to Dr. K. Aida, the University of Tokyo, for offering purified GtH of silver carp. A part of this work was supported by a grant-in-aid of research to $F$. Takashima, and $\mathrm{S}$. Ngamvongchon received a scolarship from the Ministry of Education, Science and Culture, Japan. We also wish to express our gratitude to Mr. R. Patino, Dept. Fish. Wildl., Oregon State University, for kindly reading this manuscript.

\section{References}

1) A. V. Schally, M. Arimura, A. J. Kastin, M. Matsuo, Y. Baba, T. W. Redding, R. M. G. Nair, and L. Debeljik: Science, 1973, 1066 (1971).

2) A. Van, Tienhoven and A. V. Schally: Comp. Endocrinol., 19, 594-595 (1972).

3) H. Matsuo, M. Arimura, R. H. G. Nair, and A. V. Schally: Biochem. Biophys. Res. Commun., 45, 822-827 (1971).

4) M. Arimura, M. Matsuo, Y. Baba, and A. V. Schally: Science, 174, 511-512 (1971).

5) M. Amoss, R. Blackwell, and R. Guillemin: $J$. Clin. Endocrinol. Metah., 34, 434-436 (1971).

6) M. Fujino, S. Kobayashi, M. Obayashi, S. Shinagawa, T. Fukuda, C. Kitada, R. Nagahama, I. Yamazaki, W. F. White, and R. H. Rippel: Biochem. Biophys. Res. Commun., 49, 863-869 (1972).

7) M. Fujino, S. Shinagawa, I. Yamazaki, S. Kobayashi, M. Obayashi, T. Fukuda, R. Nagayama, W. E. White, and R. H. Rippel: Arch. Biochem. Biophys., 154, $488-489$ (1973).

8) M. Sokolowska, W. Popek, and K. Bieniarz: Ann. Biol. Anim. Biochem. Biophys., 18, 963-967

Thave disappeared, and smaller granules ( $\mathrm{gs}$ ) become compact. Numerous intercellular spaces

(is) are formed.

C: Twenty-four $h$ after injection, Large and middle-sized granules have increased in

number, Endoplasmic reticuli appear to be dated.

Bars indicate $1 \mu \mathrm{m}$. 
(1978).

9) L. W. Crim, A. M. Sutterlin, D. M. Evans, and C. Weil: Aquaculture, 35, 299-307 (1983).

10) L. W. Crim, D. M. Evans, and B. H. Vickery: Can. J. Fish. Aquat. Sci., 40, 61-67 (1983).

11) T. J. Lam, S. Pandey, and W.S. Hoar: Can. J. Zool., 53, 1189-1192 (1975).

12) R. E. Peter: Can. J. Zool., 58, 1100-1104 (1980).

13) M. Sokolowska, R. E. Peter, C. S. Nahorniak, C. H. Pan, J. P. Chang, L. W. Crim, and C. Weil: Aquaculture, 36, 71-83 (1984).

14) K. K.S. Chan: Can. J. Zool., 55, 155-160 (1977).

15) K. Aida: Nippon Suisan Gakkaishi, 49, 711-718 (1983).

16) K. Aida, R. S. Izumo, H. Satoh, and T. Hibiya: Nippon Suisan Gakkaishi, 44, 445-450 (1978).

17) J. Kouruil and T. Barth: Bull. Vurh. Vodnany, 1981(1), 13-18 (1981).

18) R. Billard, J. Marcel, O. Matei, and C. Rusu: Bull. Cercetari Piscicole, 4, 29-34 (1982).

19) Cooperative Team for Hormonal Application in Pisciculture: Scientia Sinica, 20, 1469-1474 (1977).

20) The fish reproductive physiology research group: Acta. Biochem. Biophys. Sin., 10, 399-407 (1978).

21) R. Billard and J. Marcel: Aquaculture, 21, 181195 (1980).

22) C. Weil, R. Billard, B. Breton, and B. Jalabert: Ann. Biol. Anim. Bioch. Biophys., 18, 863-869 (1985).
23) C. Weil, L. W. Crim: Aquaculture, 35, 103-115 (1983).

25) F. Takashima, C. Weil, R. Billard, L. W. Crim, and A. Fostier: Nippon Suisan Gakkaishi, 50, 1323-1329 (1984).

25) M. Kobayashi, K. Aida, and I. Hanyu: Nippon Suisan Gakkaishi, 51, 1085-1092 (1985).

26) A.S. Ginzburg: in "Fertilization in Fishes and the Problem of Polyspermy", Israel Program for Scientific Translations, Jerusalem, 1972, pp. 125134.

27) F. Yamazaki and E. M. Donaldson: Gen. Comp. Endocrinol., 12, 491-497 (1969).

28) A. P. Scott, V. I. Bye, S. M. Baynes, and J. R. C. Springate: J. Fish Biol., 17, 495-505 (1980).

29) C. M. Campbell, A. Fostier, B. Jalabert, and B. Truscott: J. Endocrinol, 85, 371-378 (1980).

30) A. Fostier, R. Billard, and B. Breton: Gen. Comp. Endocrinol., 54, 378-381 (1984).

31) S. M. V. Hunt, T. H. Simpson, and R. S. Wright: J. Fish Biol., 20, 105-119 (1982).

32) M. Kobayashi, K. Aida, and I. Hanyu: Nippon Suisan Gakkaishi, 52, 755 (1986).

33) H. Ueda, Y. Nagahama, F. Tashiro, and L. W. Crim: Nippon Suisan Gakkaishi, 49, 587-596 (1983).

34) H. Ueda, O. Hiroi, A. Hara, K. Yamauchi, and Y. Nagahama: Gen. Comp. Endocrinol, 53, 203-211 (1984).

35) S. M. Baynes and A. P. Scott: Gen. Comp. Endocrinol., 57, 150-160 (1985). 